\title{
The Type-B Moral Error Theory
}

\section{Anthony Robert Booth ${ }^{1}$}

Received: 6 November 2019 / Accepted: 7 July 2020 / Published online: 5 August 2020

(c) The Author(s) 2020

\begin{abstract}
I introduce a new version of Moral Error Theory, which I call Type-B Moral Error Theory. According to a Type-B theorist there are no facts of the kind required for there to be morality in stricto sensu, but there can be irreducible 'normative' properties which she deems, strictly speaking, to be morally irrelevant. She accepts that there are instrumental all things considered oughts, and categorical pro tanto oughts (both of which she deems morally irrelevant), but denies that there are categorical all things considered oughts on pain of requiring 'queer' facts to obtain. I detail the most central motivation of this version of the theory against its more traditional rival, according to which there are no irreducible normative properties at all. The motivation is that it, unlike its rival, can successfully be defended against the notorious charge of self-defeat.
\end{abstract}

\section{Introduction}

Traditionally conceived, the Moral Error Theory (famously) comprises the following broad claims:

Semantic claim: Moral judgements have propositional content - they represent the world.

Metaphysical claim: There are no moral facts that can make the content of moral judgments true.

The upshot of these two claims has been taken to be that all moral judgements are false, and that there is no such thing as morality in stricto sensu. But it is really

Anthony Robert Booth

a.r.booth@sussex.ac.uk; arbooth@fastmail.fm

1 Department of Philosophy, University of Sussex, Falmer, East Sussex BN1 9QN, UK 
the Moral Error Theorist's metaphysical claim, and her support for it, that makes the theory distinctive (she can borrow arguments from the several kinds of Cognitivists in meta-ethics to support her semantic claim, and vice versa ${ }^{1}$ ). So the Moral Error Theory is often motivated by the so-called 'argument from queerness' (Mackie 1990), which depends on the idea that moral facts are grossly unlike any facts discovered by the natural sciences, and as such the positing of them is anathema to our modern, naturalistic world view. There are, of course, lots of different ways of understanding exactly what would be 'queer' about moral facts, and I'll say something about my preferred way of understanding this shortly. Before I get to that, however, I want to draw a distinction between two different ways of understanding the Error Theorist's metaphysical claim:

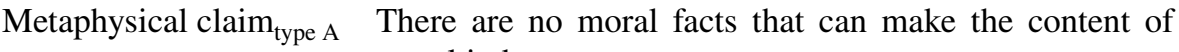
moral judgments true.

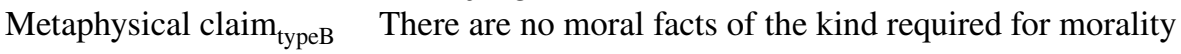
in stricto sensu.

I call the Moral Error Theory that comprises the former claim the Type-A Moral Error Theory, and that which comprises the latter the Type-B Moral Error Theory. According to Type-A Moral Error Theory, all moral judgements are false; according to the Type-B theory, some ethically insignificant moral judgements are true (but all ethically significant moral judgements are false). According to the Type-B theorist, those ethically insignificant moral judgements which can be true are all our pro tanto moral judgements. Now, both the Type-A and Type-B theories make the same semantic claim above, but often Type-A theorists will say more than merely that moral judgments have propositional content. They will often say, for example, that to say that ' $\mathrm{x}$ is wrong' is to say that ' $\mathrm{x}$ is categorically wrong' or that ' $\mathrm{x}$ is noninstitutionally wrong' (Olson 2011). The Type-B theorist is distinctive in that it (in

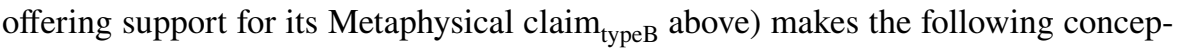
tual claim (not made by any Type-A theorists):

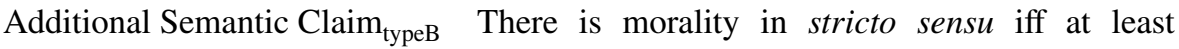
some moral obligations are all things considered obligations.

And that since no moral oughts are all things considered oughts, there is no such thing as morality in stricto sensu. But there are nonetheless irreducible (though uninformative) moral facts (so different also to Type-A theories that claim that there are none).

Though I find support for the Type-B Error Theory in a lot of what Type-A Moral Error Theorists have said, I do not think any of them have yet explicitly articulated

\footnotetext{
1 Non cognitivists may agree with the Error Theorist's metaphysical claim, but they have typically concentrated on defending the semantic claim, and its attendant issues.
} 
and defended the view. ${ }^{2}$ This paper is an attempt to do so. Every theory in metaethics comes in many different varieties, and so it should not really be a surprise that the Moral Error Theory admits of varieties too. I proceed as follows: in $\S 1$, I further articulate what I take to be the Type-B Error Theory; in $\$ 2,3$ I formulate what I take to be the central argument in its favour-that unlike Type-A Error Theory, the TypeB Theory is invulnerable to the self-defeat charge (in $\$ 2$ I show that Type-A Error Theory must be vulnerable to it, and in $\S 3$ that Type-B theory is not vulnerable).

\section{Articulating the Theory}

What I think distinguishes the Type-B theory is that it comprises the following claims:

Metaphysical claim ${ }_{\text {typeB }}$

Additional Semantic claim ${ }_{\text {typeB }}$
There are no moral facts of the kind required for morality in stricto sensu.

There is morality in stricto sensu iff at least some moral obligations are all things considered obligations.

Let's now try to make these claims clearer. I will now take the following key claims in turn: (i) that there is morality 'in stricto sensu' iff at least some moral obligations are all things considered obligations; (ii) that there are no informative moral facts that underwrite the existence of morality in stricto sensu.

\subsection{There is Morality in Stricto Sensu Iff Some Moral Obligations are All Things Considered Obligations}

Let's start with what I mean by 'morality in stricto sensu'. To understand what I mean, I think it is helpful to invoke the distinction between pro-tanto obligations (oughts) and all things considered oughts.

All things considered obligation $A$ ought to phi all things considered iff there is no competing ought that overrides it, and no excusing condition applies.

\section{Pro-tanto obligation}

A pro-tanto ought to phi iff (a) there is some fact $q$ that would make it that case that $A$ ought to phi all things considered where there not a competing ought that overrides it, and no excusing condition applies; (b) we do not know whether some fact $r$ obtains that would make it

\footnotetext{
2 The closest recent explicit endorsement is Husi (2013), I think, who defends the view that reasons are not 'authoratitive', where a reasons' being 'authoratitive' is close to, but not exactly, what I think the Type-B Error Theorist thinks is necessary for there to be morality in stricto sensu.
} 
the case that there exists an overriding ought, or some fact $s$ that would make it the case that there exists an excusing condition.

The central claim here is, of course, the following:

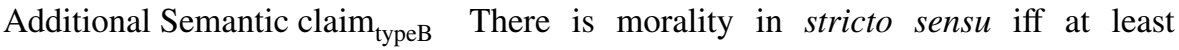
some moral obligations are all things considered obligations.

The reason for thinking this is that were we only able to make moral judgements about pro tanto obligation, we would not be able (with justification) to hold persons to be morally blameworthy. It is widely held that one can be justified in violating a moral requirement to phi if not doing so will involve violating an even stronger competing requirement not to phi. ${ }^{3}$ To say then that we can never know, for any agent $A$ and action phi, whether $A$ ought to phi all things considered would be to claim that we can never know whether $A$ has justification for violating any moral obligationand so never know whether blame would be appropriate for the violation of a moral ought.

Objection! Don't pro tanto obligations and so pro tanto moral reasons come in different strengths? And if they do, we can at least sometimes know whether $A$ has justification for violating a moral pro tanto ought $-A$ can justifiably violate a pro tanto ought to phi only if not violating the ought would involve violating a stronger pro tanto obligation not to phi. ${ }^{4}$ However, the Type-B Error Theorist can respond by claiming that this depends on how we are to understand 'strength' of reasons and oughts. First, the Type-B theorist might object: for any set of reasons or oughts that are in putative conflict with respect to whether $A$ ought to phi, those reasons are either commensurable or they are not. If they are not commensurable, then it looks wrong-headed to think those oughts have relative strengths. But if they are commensurable then that seems to presuppose a standpoint from which one can neutrally compare and so weight the reasons - that is, a standpoint from which one can determine what $A$ ought to do all things considered. Further, on one very natural way of understanding the notion, for instance, 'strength' will depend on the existence of all things considered oughts: An obligation $R$ is stronger than another $Q$ iff there are more contexts in which $R$ denotes what one ought all things considered to do than $Q$. For example: the obligation not to murder is stronger than the obligation not to lie because there are fewer contexts (situations) in which the obligation not to murder is not an all things considered ought. ${ }^{5}$ On this natural conception of what weight is,

\footnotetext{
3 See Sher (2006) for a good defence of this view.

4 Thanks to an anonymous referee for raising this objection.

5 It seems to me than Scanlon's (2014) recent view of weight is a more sophisticated version of this. For criticism of Scanlon on weight see Sampson (2015). It also seems to me that views according to which the 'weightier-than' relation is more fundamental than the notion of 'weight' (e.g. Schroeder 2007) will have to be committed to the existence of all things considered ought. See Lord and Maguire (2016) discussion and an overall fascinating collection of essays on the issue of weighing reasons.
} 
we obviously presuppose that there is such a thing as all things considered ought. Of course, there are bound to be other accounts of weight some of which (just conceivably!) might not be predicated on the existence of all things considered ought, but note that I am here merely identifying the conceptual space that a Type-B theorist can occupy_not fully defending any particular way of thinking about weight.

One might complain, for example, that the above presupposes that there is a meaningful sense to be had of an all things considered ought, or obligation simpliciter, and that morality requires there to be a standpoint from which different reasons, oughts, and obligations can be neutrally compared and commensurate. And that this is no trivial presupposition. For example, Baker (2018) has recently argued, developing work from Copp (1997), Tiffany (2007), Foot (1972), Finlay (2009) (inter alia), that there is no meaningful notion of 'ought simpliciter' to be had. This is not immediately to endorse an Error Theory, since nevertheless (as he puts it): “There may be facts about what you morally ought to do. There are certainly facts about what you rationally ought to do and what you prudentially ought to do. But there is no ought that has the job of adjudicating between these oughts" (Baker $2018 \mathrm{p}$. 230). The point here being precisely the denial of our central claim: there can be genuine moral oughts even though they are never our all things considered oughts (since there is no such thing as all things considered ought). Baker argues that anyone trying to make sense of what all things considered ought is will face a dilemma: either explicate the notion in normative terms, or in non-normative (e.g. psychological terms). If you explicate it in normative terms (such as 'that ought which one must follow' or 'that ought which is authoritative', or 'that ought which trumps all others'), you end up with a circular, non-informative characterization. But if you explicate it in non-normative terms, you fail to give an account of the authority of all things considered ought. But I think the defender of the central claim here works with the following characterization: you are blameworthy for phi-ing iff you violate an all things considered ought. While blameworthiness is a normative notion, I do not think it is uninformative to characterize the all things considered ought in terms of this notion-not in the way that characterizing it in terms of 'authority', or 'trumping', is. One could complain that this move presupposes that there is only one kind of blame, and that there may be more-that there may be, for example, epistemic blame, distinct from moral blame. I find the idea there being distinct types of blame a suspect one (as I have argued in Booth 2012, and see also Nottelmann 2017 on epistemic blame) when it is something over and beyond the idea that there can be differing reasons that can determine whether or not one is blameworthy (and this idea is compatible with the existence of all things considered ought). The challenge is for the defender of types of blame to give an account of why these putatively different sorts of blame are members of the genus 'blame' in a way that does not invalidate the idea that they are cannot be compared in an all things considered judgement. I do not think this challenge can be met, but, again, I am here merely identifying the conceptual space that a Type-B theorist can occupy. ${ }^{6}$

\footnotetext{
${ }^{6}$ Further, see Thomson (1994) and Rowland (2016) for defences of ought simpliciter. Thanks to an anonymous referee for encouraging me to address this point.
} 


\subsection{There are No Informative Moral Facts that Underwrite the Existence of Morality in Stricto Sensu}

What sort of moral facts are required by the Type-B theory for there to be morality in stricto sensu? I think it helps here to make a further distinction between conditional obligations and categorical obligations, and the facts attending each:

Conditional Obligation $A$ conditionally ought to $x$ iff $A$ 's obligation to $x$ is grounded in some fact q whose obtaining depends on $A$ 's ends, desires, institutional or other roles and activities.

Categorical Obligation A categorically ought to $x$ iff A's obligation to $x$ is grounded in some fact $\mathrm{q}$ whose obtaining does not depend on A's ends, desires, institutional or other roles and activities. ${ }^{7}$

According to the Type-B theorist, morality in stricto sensu requires the existence of facts relevant to 'categorical' obligation above. This is because they can hold that any claim about a conditional obligation is alone morally uninformative. ${ }^{8}$ They can-surely not completely unreasonably - think that there is an infinite number of things that people either actually desire (have as an end), or will desire in the future. For any $\mathrm{x}$, there is some $A$ who either does or will or has desired x. So every fact (or any subjective state, depending on your ontology of reasons) is a potentially protanto reason, since it is a reason for some agent $A$ to phi-modulo $A$ can update her desires and ends accordingly, and we accept that facts which generate instrumental

\footnotetext{
7 See Olson (2011) for a similar definition.

8 See Earman et al. (2002) for a similar claim about ceteris paribus laws in science-though for them this means the validity of such laws is compromised. Vayrynen $(2006,2009)$ defends the idea that there are ceteris paribus moral principles (which he sometimes equates with pro tanto moral reasons) against a similar charge (that they have no explanatory value) (see also McKeever and Ridge 2006). Another argument against conditional obligation is found in Bovenak (1998). It's important to note, however, that the Error Theorist here does not need to deny the following claim: if there are facts that determine the relative weight of competing pro tanto reasons and oughts then pro tanto reasons and oughts are informative. She just claims that since there are no such facts, pro tanto reasons and oughts are uninformative.
} 
reason can also generate pro tanto oughts. ${ }^{9}$ This will commit the Type-B theorist to a kind of pan-proto-normativism: every fact is potentially a normative fact.

Like pan-proto-psychism, I think we can consider the view to be naturalistically kosher. Note that pan-proto-normativism is not the following view: every fact is potentially a fact that determines what one ought to do all things considered. Knowing about the existence of a pro tanto reason is morally uninformative (though it may tell us about the existence of some non-moral fact) unless there is some mechanism or set of principles that enables one to discern the facts of how pro tanto oughts and reasons play off against each other such that we know what we ought to do all things considered. Put differently, knowing that I have pro tanto reason to phi means either that I have instrumental reason to phi relative to one of my existing ends, or I would have reason to phi if I update my preferences. What I don't know just by knowing that I have pro tanto reason to phi is whether I have a competing reason, relative to other ends, not to phi, or whether I ought to update my preferences. In other words, I don't know what I ought to do all things considered. What the Type-B Theory denies is that there is any such mechanism or set of principles that can determine what one ought to do all things considered, or that there is any fact that determines this that can be somehow directly intuited.

There are thus 4 kinds of ought for the Type-B theorist:

\section{Categorical, all things considered obligation}

\begin{abstract}
Necessary for morality in stricto sensu. Facts that would generate these would be queer, however.
\end{abstract}

\footnotetext{
${ }^{9}$ It is for this reason that there is no easy reduction strategy for Prudential Ought. Fletcher (2017), for example, illustrates the idea in terms of an analogue of Morgan and Timmons familiar 'moral twin earth' thought experiment: "On prudential twin earth 1, agents have a form of discourse connected to the exercise and development of unique human capacities. They hold that theoretical contemplation is the only uniquely human capacity, and it is plausible that they hold that only this activity has prudential value (and that its value in no way depends upon it being pleasurable). Evidence for this commitment comes from the advice that they give each other ('only have fun if it helps your contemplation', 'only exercise if it helps your contemplation'), and from how they structure their lives both as individuals and as a society. For example, people only non-instrumentally desire contemplation for themselves, they reliably seek it out for themselves and for their loved ones, they envy those with more contemplation time than themselves, and so on. For these reasons, it is plausible that they make prudential judgments and that their conception of prudential value is one that ties it to what is unique to humans and to theoretical contemplation. By contrast, on prudential twin earth 2, agents have a similar form of discourse that is connected to pleasure and pain. It is plausible that they hold that only these hedonic phenomena have prudential value (or disvalue). Evidence for this comes from the advice that they give ('have fun!', 'only exercise if it feel good') and from how they structure their lives as individuals and society." (Fletcher 2017, p. 7). According to Fletcher, this causes problems for the Error Theory, since-via parity of reasoning-they are forced to admit that there is no real Prudential Ought, and as such that claims like $<$ pain is sometimes bad for those who experience it $>$ are strictly false claims (cf. Fletcher 2017 p. 8). However, on Type-B Error Theory, the Error Theorist is happy to concede that pain is sometimes bad for those who experience it, but thinks that the claim is — on its own - practically, or prudentially uninformative. The fact that this version of the Error Theory evades this new kind of objection (as raised by Fletcher) ought to justify having a less incredulous attitude toward it.
} 
Conditional, all things considered obligation

\section{Categorical, pro tanto obligation}

\section{Conditional, pro tanto obligation}

Irrelevant for morality in stricto sensu (because conditional), but does not require the positing of 'queer' facts or properties.

Irrelevant for morality in stricto sensu (because pro tanto), but does not require the positing of 'queer' facts or properties. Irrelevant for morality in stricto sensu (because conditional, and pro tanto), but does not require the positing of 'queer' facts or properties.

The type-B Error Theorist denies only the existence of categorical, all things considered obligations. ${ }^{10}$

\subsection{Why are the Properties Required for There to be Morality in Senso Strictu are 'queer'?}

There is a sense in which the Type-B theory accepts the existence of irreducibly "normative" properties. But only in a very deflationary sense of what "normative" means, since these "normative" facts and properties could not alone be relevant to morality in senso strictu. ${ }^{11}$ The Type-B theorist is committed to the non-existence to moral facts relevant to all things considered, categorical ought, on pain of such facts seeming out of place in a naturalistic world view ontology (according to which the only things that exist are the things discoverable by the natural sciences) ${ }^{12}$ and that the absence of such facts means there is no such thing as 'morality' proper. ${ }^{13}$ But one might wonder why they are deemed so strange, while irreducibly normative facts about pro tanto obligation are not. After all, it has been the irreducibility of normative properties that has often been taken to be the key feature thought to generate "queerness"- since if they were naturalistically reducible they would be ipso facto part of a naturalistically-friendly ontology. But obviously the fact that they would fail to be odd if they were reducible does not mean that it is necessarily their irreducibility that is peculiar. In fact, in Mackie's Error Theory classic Inventing Right and Wrong, he highlights specifically the property of "intrinsic-to-be-pursuedness"

\footnotetext{
${ }^{10}$ Hence the difference with Husi (2013), who thinks that a reasons sceptic denies that reasons are authoritative when 'authoritative' entails categorical or 'un-conditional' (p. 427). The Error Theory under consideration does not necessarily deny that reasons are categorical, since they could be categorical, pro tanto.

11 See Finlay $(2008,2009)$ for another deflationary view of irreducible normative that he claims is perfectly compatible with naturalism.

12 See Parfit (2017) for criticism of this version of naturalism. I won't here seek to defend it.

13 If, as per Stephen Finlay's 'end-relational view' (Finlay 2008) moral reasons are always relative to some end or standard, then the Error Theorist is happy to accept there is such a thing as 'morality'. The debate between these two camps would be merely verbal. See Das (2017) for a defence of the idea that, out of conceptual necessity, moral reasons are categorical.
} 
as the smoking gun, "queer" property. The Type-B theorist interprets "intrinsic-tobe-pursuedness" to be about non-optionality. Normative facts relevant to morality proper would be normative facts that themselves (hence 'intrinsic'), also determine obligations that cannot be evaded (hence 'to-be-pursuedness') and this is a way of saying that morality itself is non-optional.

Underlying the view is an account according to which facts that generate instrumental reasons only generate pro tanto oughts. This is because unless $A$ 's relevant goals, ends, desires, institutional or other roles, and activities are somehow noncontingent, then $A$ could evade her obligation by relinquishing one of the latter. By 'evading' I mean that $A$ could cease being obliged to $\varphi$ without violating her obligation to $\varphi$. On this view, all things considered ought is to be thought of along something like the following lines:

\section{All Things Considered Ought (non-evaded)}

$A$ ought $_{\text {atc }}$ to $\varphi$ iff $A$ 's obligation to $\varphi$ cannot be evaded

Some people won't like the non-evadability way of thinking about all things considered ought, since they will want to insist that pro tanto ought cannot be evaded eitherif I ought to phi, but have an even stronger obligation not to phi, then I ought to not to phi all things considered, but that does not mean that the ought to phi has disappeared, or has been evaded (see, for example, Williams 2008). ${ }^{14}$ I think this worry can be parried by clarifying what exactly I mean by an obligation that cannot be evaded:

Non-Evadability $A$ 's obligation $\mathrm{O}$ to phi cannot be evaded iff there is no way $A$ can blamelessly violate $\mathrm{O}$.

In other words, an obligation cannot be evaded if there is no stronger competing ought that overrides it and no other excusing condition will apply.

Nevertheless, this does not seem to be the way in which many meta-ethicists define all things considered ought. And this might be taken to be a reason for resisting the claim that the Type-B theorist can accept the existence of categorical, pro tanto reason and oughts. Many philosophers, at least implicitly, seem to think of all things considered ought in terms of whether or not that ought has been overridden by a competing obligation, along something like the following lines instead:

All Things Considered Ought (non-overridden) $\quad A$ ought $_{\text {atc }}$ to $\varphi$ iff there is no stronger, competing ought for $A$ not to $\varphi .{ }^{15}$

\footnotetext{
14 Thanks to an anonyous referee for discussion here.

15 Cf. Hare (1981). Some philosophers add the caveat that not only must the ought not be overridden, but that it must itself override any competing oughts:
}

An all things considered obligation represents what one ought to do in light of all morally relevant factors, including alternatives. If so, then only prima facie obligations that are undefeated and defeat all competitors are all things considered obligations. In other 
It seems to me that the former way of thinking of what all things considered ought is, is logically stronger than the latter, in that it entails (but is not entailed by) it. This is because we should not simply assume here that instrumental reasons cannot generate all things considered ought. As such, an ought generated by instrumental reason may not be overridden by any other ought, but yet may be evaded if it is permissible for the agent in question to modify accordingly whatever her goals, ends, desires, institutional or other roles, and activities that are generating her instrumental reason. Brink's principle that all things considered oughts must be overriding (not merely not overridden) may block this move, if we take the idea that all things considered oughts are overriding to mean that they cannot be evaded. But that is quite a strong way of reading the overriding requirement, since we may think (again not already ruling out that facts that generate instrumental reasons can generate all things considered oughts) that, for example, given $A$ 's goals and ends there is some fact q that makes it the case that $A$ ought to $\varphi$, and given $A$ 's goals and ends that ought is overriding. But $A$ may nevertheless choose to update her relevant goals and ends and then no longer be obliged to $\varphi .{ }^{16}$

It seems to me that all things considered oughts should then be thought of in the non-evaded sense above, since only that way of understanding them does justice to the idea that moral oughts are strictly non-optional-and it is this feature that is thought to be distinctive of morality proper, at least by some Type-A Error Theorists (e.g. Joyce 2001). So if what is odd is about putative moral properties is their the non-optionality, then it is the existence of facts that would determine all things considered obligations that would be odd-facts that determine merely pro tanto obligation are not odd. Facts that determine merely pro tanto obligation are not at odds with a naturalistic world view, since they are explicated in terms of our desires, roles, institutions etc. But facts that determine all things considered obligations are at odds with a naturalistic world view, since there is nothing in the natural world that can give a neutral weighting of the normative facts underlying pro tanto oughts (no facts that determine, for instance, why it is better all things considered to be a policewoman over being a lawyer). That is, no facts in the natural world can tell us what are our all things considered moral obligations.

This completes my description of the Type-B Error Theory. I now move to articulate what I take to be the central reason for meta-ethics to at least give it some consideration-it unlike its rival in Error Theory can evade the notorious charge of self-defeat. ${ }^{17}$

\footnotetext{
Footnote 15 (continued)

words, to be an all things considered obligation, a prima facie obligation must be overriding and not simply not overridden (Brink 1994, p. 240).

16 I take it to be fairly obvious that the 'non-evaded' way of thinking about all things considered oughts entails the 'non-overriden' way of taking them, given how I have defined what it is to be able to 'evade' an ought (i.e. as being able to violate it without being blameworthy, and in the absence of any relevant excusing conditions).

17 In responding to Husi (2013), Case (forthcoming) writes: "Someone might be tempted to reply as follows: "what the error-theorist rejects is authoratitve normative reasons, not instrumental or non-categorical reasons'. That response amounts to moving the goal-post. Error theory was defined at the outset as the view that 'normative judgements are beliefs that ascribe normative properties, even though such
} 


\section{The Self-defeat Argument Against the Error Theory}

Here is how the self-defeat argument against the (Type-A) Error Theory traditionally has gone. The Moral Error Theorist denies that there are moral reasons and moral oughts. But then should not the Error Theorist, on pain of inconsistency, also deny that there are reasons for belief (hereafter categorical epistemic reasons)? It seems she should. But if she does, she must also then deny that there are reasons for her to believe the Moral Error Theory. ${ }^{18}$ But if we take the Error Theorist to make a distinction between categorical and conditional ought (and accept the existence of conditional oughts and reasons) we should be more precise and charge that she should deny that there is categorical reason for her to believe the Moral Error Theory. But this still looks like a problem for the Error Theorist because epistemic reasons, it seems, must be categorical. To say that I have epistemic reason to believe that $\mathrm{p}$ is to say that I have good evidence in favour of p, so the thought goes. And whether or not evidence is good cannot depend on what my ends are with respect to a belief that p. For instance, I might not have a desire to know (i.e. have a belief about) whether Henry VII won the battle at Bosworth Field, but if my persistent, reliable history teacher makes sure that I hear her say that he did win it, I have epistemic reason to believe it. As Thomas Kelly puts the point: "one cannot immunize against the possibility of acquiring reasons for belief by not caring about the relevant subject matter" (Kelly 2003, p. 628). By 'epistemic reason', incidentally, we mean a reason for belief that is regulated by the twin aim of believing truths and avoiding falsehoods.

To summarise the objection: if epistemic reasons must be categorical, it follows that an Error Theorist about categorical reasons must deny that we have reasons to believe any proposition. And thus that there is no reason to believe the Error Theory.

The most obvious way to respond to this charge is to invoke a distinction between reasons for belief and evidence, where only the former notion involves the normative assessment of belief. Evidence is here thought to comprise propositions that raise the probability of another proposition's being true. The thought is that having evidence toward a proposition is one thing, but the evidence constituting reason to believe that $\mathrm{p}$ is quite another. There is evidence that Jim moved a pebble to the left in Aberdeen, but on its own, that evidence does not give you any reason to believe anything.

So the Error Theorist could claim that she is merely offering evidence for the claim that the Error Theory is true, she is not thereby offering anyone reasons to believe the Error Theory.

Footnote 17 (continued)

properties do not exists', This rules out categorical and hypothetical reasons alike." It should be easy to see how the Type-B theory evades this objection: it is explicitly a different kind from the error-theory defined 'at the outset', and interesting in its own right, but yet retains aspects that distinguish it from normative subjectivism or instrumentalism, in that it holds that there is no such thing as morality in stricto sensu.

18 Cf. Bedke (2010), Cuneo (2007), Scanlon (1998), Stratton-Lake (2002). 
But people have noted there to be, at least, two problems with this move:

( $\varphi$ ) It makes the error theory "polemically toothless" (Cuneo 2007, p. 117).

( $\psi)$ Evidence is a normative concept (Kelly 2003, 2007).

Both Streumer $(2013)$ and Olson $(2011,2014)$ have recently attempted to defend the Error Theory via the distinction between reasons for belief and evidence. My main concern, however, will end up being with $(\psi)$, since I think that Olson's response to $(\varphi)$ goes through, but that he does not adequately deal with $(\psi)$. Streumer's response to ( $\psi)$ I think is costly in that it is predicated on the claim that we cannot believe that Error Theory, but that it is a virtue of the Error Theory that it predicts that we cannot believe it. As such, his defence will succeed only of he can show that he can make this move without being vulnerable to charge $(\varphi)$. He tries to do this by appealing to the idea that we can nonetheless come close to believing the Error Theory. I think there are several issues with this move, one of which is that he seems to equivocate on what it is to "come close" to believing in an important way-I come can "come close" to believing something in that while, for example, naïve set theory may seem to be true, I know that it cannot be; or can "come close" to believing something because while I think that there is good evidence for it, it is not quite good enough to warrant not simply suspending judgement on the question of whether it is true. Unfortunately, I do not have the space to develop this objection here, but see Lillehammer and Möller (2015) for a full treatment on a similar concern, and Hyun and Sampson (2014) for some further criticisms.

My diagnosis is that Streumer (errantly) accepts the false assumption that reasons for belief must be categorical. And he presumably does so (accepts that reasons for belief must be categorical) for the reasons that Kelly gives and because he thinks that epistemic reasons would not have polemical caché if they were not categorical. But Kelly's case for the claim that epistemic reasons are categorical also backs up, as I will show shortly, as a case for claiming that evidence is normative. So that the Error Theorist is best off denying both the categoricity of epistemic reasons and the normativity of evidence.

And that is how Jonas Olson defends the error theory against the charge that it is polemically toothless. He responds by reminding us that since Error Theorists are not committed to denying that there are instrumental reasons for belief, they can accept that their arguments are polemically toothless when they are engaging with people who do not have the desire to believe the truth about meta-ethics, or are not engaged in the activity of discovering the truth in meta-ethics, or in some activity that gives them instrumental reason not to reject the conclusion that the arguments the Error Theorist offers leads to (assuming the latter are sound, of course).

Olson also responds to Kelly's charge that evidence is normative. It is important to see, however, that Kelly has two arguments for that claim, and that the second is also an argument for the claim that epistemic reasons are categorical. Olson responds to this objection from Kelly:

...on the view that evidence has no normative force of its own, it is mysterious why an explicit judgement to the effect that one's evidence strongly supports some proposition typically results in a belief that that proposition is true (Kelly 2007, 468-9). 
This objection concerns the fact that we typically believe that $\mathrm{p}$ if we believe that our evidence "strongly supports" that $\mathrm{p}$.

The other objection Kelly levies concerns our having the intuition that $\mathrm{S}$ ought to believe that $\mathrm{p}$ when $\mathrm{S}$ believes that $\mathrm{S}$ has evidence that strongly supports that $p$, regardless of what $S$ 's ends are as regards $p$. This is the point I mentioned earlier with respect to the impossibility of our "immunizing" ourselves from acquiring epistemic reasons by not caring about the relevant subject matter. This intuition tells against the idea that epistemic reasons are instrumental, but, crucially, it also supports the idea that evidence is normative (in that evidence gives us all things considered reason to believe) - my acquiring evidence that Henry VII won the battle of Bosworth is on its own enough to illicit the intuition that I ought to believe it. What best explains this? The fact that evidence is normative. ${ }^{19}$

Olson's reply to Kelly is to say:

Explicit judgements to the effect that one's evidence strongly supports $p$ typically result in belief that $p$ because, typically, when we assess evidence for and against $p$ we do so because we recognize non-categorical reasons to have true beliefs as to whether $p$; we want to know whether $p$, we are interested in whether $p$, and we believe that were we to believe in accordance with evidence with respect to whether $p$ we would come to know whether $p$ (Olson 2011, p. 90).

I agree with Olson that this dispatches the first of Kelly's concerns that I mentioned. However, it is clear that it does not dispatch the second concern of Kelly's that I have identified. That is, the fact that we typically do have some relevant ends regarding $\mathrm{p}$ that explain why we end up believing $\mathrm{p}$ in the face of evidence in favour of $\mathrm{p}$, does not explain away the intuition that even when we do not have such ends (or have ends to the contrary), we still ought-all things considered-to believe that $\mathrm{p}$. The claim that epistemic reasons are instrumental predicts that we do not have such an intuition. Given that Olson does not address this problem, there is still work to be done in defence of the Error Theory. His defence, as I mentioned, is incomplete. It is in response to this last concern that I think my formulation of Error Theory, as the claim that there are no categorical and all things considered reasons, makes headway where other versions do not.

\footnotetext{
${ }_{19}$ We should note that we are talking about subjective evidence here - that is, evidence I am aware of. We do not have the same intuition, it would seem, about objective evidence. Thanks to an anonymous referee for pointing this out. I should also point out that when I say evidence that $\mathrm{p}$ (unless I specify otherwise) I mean conclusive evidence that $\mathrm{p}$. What is it to have conclusive evidence? That's a very difficult question, and I won't be able to answer it here.
} 


\section{All Things Considered Reasons for Belief and Evidence Come Apart}

As we have seen, in order to evade the self-defeat charge, the Error Theorist has often appealed to a distinction between evidence and reasons for belief: she is merely claiming that there is evidence in favour of Error Theory, she is not thereby claiming that there are reasons to believe the Error Theory. As we have discussed, the trouble is that evidence seems to be normative. That is, on acquiring evidence, such as evidence that Henry VII won the battle of Bosworth, we seem to acquire reasons for belief that we cannot immunize ourselves from by not caring about who won that battle, and such that we ought - all things considered - to believe that Henry VII won that battle. One reason to think this is that we have the intuition that not only does $\mathrm{S}$ have pro tanto reason to believe that $\mathrm{p}$ on acquiring sufficient evidence that $\mathrm{p}$, but that $\mathrm{S}$ has all things considered reason to believe that $\mathrm{p}$ on acquiring the evidence. On this reading, the claim that evidence is normative means not only that acquiring sufficient evidence that $\mathrm{p}$ always gives rise to reasons to believe that $\mathrm{p}$, but also that those reasons are all things considered. This explains why-if one possesses evidence for a proposition-non-evidential (non-epistemic) reasons for belief seem to be irrelevant to the question of whether $S$ ought to believe that $p$, and this explains why hypothetical considerations that are not about evidence are irrelevant regarding whether $\mathrm{S}$ ought to believe that $\mathrm{p}$. The claim that epistemic reasons are not instrumental then follows from this stronger claim about the normativity of evidence (that acquiring evidence that $\mathrm{p}$ makes it the case that one ought to believe that $\mathrm{p}$ ). If epistemic reasons were instrumental, it would not always be the case that on acquiring evidence that $\mathrm{p}, \mathrm{S}$ ought all things considered to believe that $\mathrm{p} .{ }^{20}$ As I mentioned in the last section, Olson's reply does not address this way of taking Kelly to be presenting a case in favour of the normativity of evidence.

I now offer an argument for the claim that evidence cannot be normative in this strong sense. That is, the claim that $\mathrm{S}$ has epistemic reason to believe that $\mathrm{p}$ is not, taken alone, the claim that $\mathrm{S}$ has all things considered reason to believe that $\mathrm{p}$. Before I do so, I think it would be useful here to recall the claim I made in $\S 1$ that the Type-B Error Theorist can accept that there are categorical pro tanto reasons and oughts. As such, her position will only be incompatible with the stronger of the two readings below of 'evidence is normative' (given that the Type-B theorist can accept the existence of pro tanto norms and reasons):

$\begin{array}{ll}\text { Evidence is normative }_{\text {strong }} & \begin{array}{l}\mathrm{S} \text { has sufficient evidence that } \mathrm{p} \text { iff } \mathrm{S} \text { all things consid- } \\ \text { ered ought to believe that } \mathrm{p}\end{array} \\ \text { Evidence is normative }_{\text {weak }} & \begin{array}{l}\mathrm{S} \text { has sufficient evidence that } \mathrm{p} \text { iff } \mathrm{S} \text { pro tanto ought } \\ \text { to believe that } \mathrm{p}\end{array}\end{array}$

\footnotetext{
${ }^{20}$ There may be excusing conditions for this ought, but these are going to take the form of defeaters (undercutting or overriding), e.g. that we have reason to believe the evidence is misleading. One might think that having defeaters with regards to evidence that $\mathrm{p}$ means that the 'evidence' that $\mathrm{p}$ is not really evidence. Whether that view is right is a difficult question, and I'm afraid I won't have the space to try to answer is here. Luckily, I don't think the tenability of the position I want to defend here hangs on it.
} 
As I just mentioned above, Kelly's case seems to give us support for the stronger principle, and if this principle is true, then the Error Theory (of both types) is in trouble. This is because, as I mentioned, the Type-B Error Theorist accepts that there are categorical reasons, so long as they are not also all things considered reasons. If evidence that $\mathrm{p}$ generates categorical and all things considered reasons, then the Type-B Error Theory is false. Why isn't the Type-B theory self-defeating merely if evidence that $\mathrm{p}$ always gives $\mathrm{S}$ (pro tanto, at least) categorical reasons to believe that $\mathrm{p}$ ? This is because the Type-B theorist could claim that, in defending her theory, she is offering reasons that $\mathrm{p}$ that don't always amount to an all things considered reasons to believe that $\mathrm{p}$, and that, as such, failing to believe the Type-B Error Theory on the basis of her argument is not always a rational mistake. Whether it is a rational mistake will depend on what her ends are (and so that her position is not polemically toothless either, to people with the relevant ends).

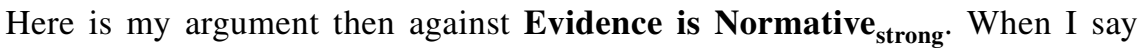
that 'evidence is normative' below, I mean it in the strong sense.

1. Evidence is normative iff sufficient evidence that $\mathrm{p}$ on its own always generates all things considered reasons (oughts) for $S$ to believe that $\mathrm{p}$.

2. Sufficient evidence that $\mathrm{p}$ does not on its own always generate all things considered reasons for $S$ to believe that $\mathrm{p}$.

3. Evidence is not normative.

As I mentioned, I here simply take 'evidence' to be something that determines whether or not some proposition(s) $\mathrm{p}$ [the evidence] raise the probability of another proposition q's being the case.

I think that premise 1 can be defended rather easily, provided we are working with Evidence is Normative $_{\text {strong: }} \mathrm{S}$ has sufficient evidence that $\mathrm{p}$ iff $\mathrm{S}$ all things considered ought to believe that $\mathrm{p}$. If something other than evidence could generate categorical and all things considered doxastic oughts then it would not be the case that having an all things considered obligation to believe that $p$ was sufficient for S's having sufficient evidence that $\mathrm{p}$ - her prudential reasons, for instance, might make it the case that she ought all things considered believe that $\mathrm{p}$, regardless of whether she does not have sufficient evidence that $\mathrm{p}$. The Kelly cases we discussed are supposed to support the idea that her moral reasons would always be irrelevant as to whether she ought to belief.

However, I think that evidence does not always generate all things considered reasons to believe that $\mathrm{p}$ for any subject $\mathrm{S}$ (as per premise 2). I think this because it is the case that what evidence we have cannot, alone, determine what evidence we ought to have. Suppose that I morally ought not snoop into my boss's e-mail account (or even prudentially ought not to-it is very likely that I will get fired if I get found out). However, I violate this obligation and come to have evidence that our institution's account number is 78645 . The only way I could have arrived at the belief that the account number is 78645 is to have violated the obligation not to hack my boss's e-mail account. Ought I all things considered to believe 
that 78645 is the account number? If evidence is normative (in the stipulated strong sense) then, yes, I ought to. But it seems to me far from clear that that is what pre-theoretically we would be minded to say, given that I have violated a norm in acquiring the evidence I have.

I think it is pre-theoretically natural to say instead that relative to my evidence I ought to believe that the account number is 78645 (I ought epistemic $_{\text {to believe that }}$ p) but that there is a competing ought (moral or prudential, perhaps) according to which I ought not to. ${ }^{21}$ What then determines what I ought to believe all things considered? Here are the options:

$\alpha \quad$ The ought determined by the evidence (ought epistemic $_{\text {) }}$ always trumps competing oughts. So I ought all things considered to believe that the number is 78645

$\beta$ There is no generalist norm (or set of generalist norms) that covers what one all things considered ought to believe. [Doxastic particularism]

$\gamma \quad$ There are no such things as all things considered doxastic oughts

The problem is that on all of them, evidence is not normative in the strong reading. So none will help the opponent of the Type-B theory win an argument by enlisting the claim that evidence is normative. Take $\alpha$ first.

If ought $_{\text {epistemic }}$ trumps other oughts (as per $\alpha$ ) then there is a norm or rule that settles this trumping. This trumping norm cannot itself be evidence-evidence on its own is not a norm. Is there evidence that settles that belief in this trumping norm itself ought ${ }_{\text {epistemic }}$ to be believed? It seems at least unclear what such evidence would even look like. And so I do not think the Error Theorist is by any means forced to concede that there is such evidence. As such, if the norm has any authority, it must have it for non-evidential reasons-such that evidence alone would not be doing the normative work in determining that I ought all things considered to believe that the number is 78645 in the example.

If on the other hand, $\beta$ is true, then we should ask: what does determine what one ought to all things considered believe? If it is always just the evidence, then a generalist norm would cover what we ought to all things considered believe (something like the Lockean:<always proportion your doxastic attitude to the evidence $>$ ), so you would have to deny $\beta$. So to espouse $\beta$ is to admit that things aside from evidence can determine what one all things considered ought to believe.

Perhaps then we should think that the oughts here are not in competition: that the norms governing what evidence we ought to have are not after all doxastic oughts, in that they do not govern what we ought to believe. These norms are solely about what evidence we ought to collect, consider, ignore thought of as actions not beliefs. Properly doxastic norms prescribe only what our doxastic attitudes should be relative to

\footnotetext{
21 Some might complain that since we cannot believe at will, we cannot be morally evaluated for our beliefs. I doubt that is our pre-theoretical intuition, however. For evidence for this claim from X-Phi, see Buckwalter et al. (2018). Some philosophers reject the idea that we cannot believe at will (Descartes most notably) and many think that we can be morally evaluated for them despite the truth of doxastic involuntarism, such that there isn't really a consensus view (for an excellent, recent, book length treatment of this issue see Peels 2017). Thanks to an anonymous referee for raising this.
} 
the evidence. The trouble here is that it is implausible that norms determining what evidence we should consider and collect have no bearing whatsoever on what our doxastic attitudes ought to be. Presumably we ought to consider evidence because we want to end up with the right doxastic attitudes. Further, given that belief is usually held to be involuntary (so determined by our subjective evidence), what we believe is going to heavily supervene on what evidence we have. So one might then be minded to reject that there is such a thing as all things considered doxastic ought, and that is why the oughts are not really in competition (as per $\gamma$ ). I ought moral $_{\text {not }}$

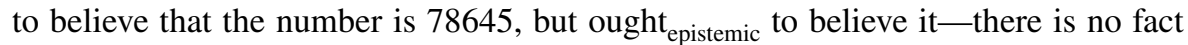
of the matter about what I ought to believe all things considered. This is the line taken usually taken by people who defend the normativity of evidence (cf. Feldman (2000) and Kelly (2003) who deny that there is such a thing as "just plain ought to believe" - what I take to be all things considered ought to believe). ${ }^{22}$ But the Type-B theorist can happily concede this, since, as I have mentioned, she is only interested

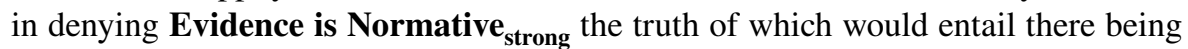
all things considered doxastic oughts. But does this not put pressure on the claim that there is morality proper iff at least some moral oughts are all things considered oughts? Only if it already assumed that there is morality proper. And it would be question begging to assume this against the Error Theorist.

In short then, if there are norms other than our evidence that can do the appropriate normative work in settling what we ought to all things considered believe, then par excellence epistemic norms (qua epistemic norms), alone, do not always generate categorical doxastic ought (and thus evidence is not normative). If there are no such other norms, then we accept a kind of normative nihilism, where what we ought all things considered to believe is arbitrary from a normative point of view, and the idea that evidence is normative in the strong sense no longer really makes sense. If evidence is not normative in the strong sense, then the Type-B theorist can legitimately appeal to the claim that evidence and reasons for belief can come apart-by giving us sufficient evidence for her theory, she has not thereby given us all things considered reason to believe it. The argument I have given does not rule out that epistemic norms can generate all things considered categorical reasons to believe, ${ }^{23}$ but it rules out that they do so because evidence is normative. In then end, Kelly's cases as regards the impossibility of our immunizing ourselves from acquiring reasons for belief by not caring about the relevant subject matter actually end up supporting that last claim. This is because they bring to bear an intuition that where I receive sufficient evidence that $\mathrm{p}$ then I ought all things considered believe that $\mathrm{p}$. How do we explain that intuition? We can either appeal to a non-epistemic weighing norm to explain the intuition (but if there is such a non-epistemic norm, evidence is not normative); else there is no such weighing norm, but then the intuition becomes mysterious.

\footnotetext{
22 Thanks to an anonyous referee for pushing me on this point.

23 Though to the error theorist facts that putatively generate such reasons will seem "queer" or mysterious.
} 


\section{Conclusion}

In sum, then, I hope to have shown that the Type-B theorist has a case for thinking that all things considered reasons for belief are not categorical at her disposal. And, it is a case that gives us the resources to deal with the cases meant to support the claim that epistemic reasons are categorical, cases that have not been dealt with by the existing defenses of the Error Theory. ${ }^{24}$ By defending the Type-B theory in this way, we can reject an unqualified rendering of a vital premise that appears in both anti Error Theory arguments as well as arguments in its favour (e.g. Streumer 2013) that work on the premise there are no reasons to believe the Error Theory. If we believe the Type-B Error Theory, we are committed only to believing that there are no categorical and all things considered reasons to believe it-if the reasons to believe the Error Theory are categorical then they are merely pro tanto, so uninformative. So that we can believe an Error Theory, and claim that our evidence supports it. But we can believe it only for non-categorical reasons; for this Error Theorist, the only informative reasons there are..$^{25}$

Open Access This article is licensed under a Creative Commons Attribution 4.0 International License, which permits use, sharing, adaptation, distribution and reproduction in any medium or format, as long as you give appropriate credit to the original author(s) and the source, provide a link to the Creative Commons licence, and indicate if changes were made. The images or other third party material in this article are included in the article's Creative Commons licence, unless indicated otherwise in a credit line to the material. If material is not included in the article's Creative Commons licence and your intended use is not permitted by statutory regulation or exceeds the permitted use, you will need to obtain permission directly from the copyright holder. To view a copy of this licence, visit http://creativecommons.org/licen ses/by/4.0/.

\section{References}

Baker, D. (2018). Skepticism about the ought simpliciter. Oxford Studies in Metaethics, 13, $230-252$.

Bedke, M. (2010). Might all normativity be queer? Australasian Journal of Philosophy, 88, 41-58.

Booth, A. R. (2012). All things considered duties to believe. Synthese, 187, 509-517.

Bovenak, D. (1998). Against conditional obligation. Nous, 32(1), 37-53.

Brink, D. (1994). Moral conflict and its structure. Philosophical Review, 103(2), 215-247.

Buckwalter, W., Turri, J., \& Rose, D. (2018). Choosing and refusing: Doxastic voluntarism and folk psychology. Philosophical Studies, 175(10), 2507-2537.

Case, S. (2019). The normative error theorist cannot avoid self-defeat. Australasian Journal of Philosophy (forthcoming).

Copp, D. (1997). The ring of Gyges: Overridingness and the unity of reason. Social Philosophy and Policy, 14(1), 86-101.

Cowie, C. (2014). In defence of instrumentalism about epistemic normativity. Synthese, 191(16), 4003-4017.

Cuneo, T. (2007). The normative web. Oxford: Oxford University Press.

\footnotetext{
${ }^{24}$ I think this is true of other defences of Epistemic Intstrumentalism that I have not discussed, such as Cowie (2014).

25 With thanks to Corine Besson, Daan Evers, an audience at Cardiff University, my Ethics and Normativity class at the University of Sussex, and anonymous referees for this journal and another for great comments on this or earlier versions of this paper.
} 
Das, R. (2017). Bad news for moral error theorists: There is no master argument against the companions in guilt strategy. Australasian Journal of Philosophy, 95(1), 58-69.

Earman, J., Roberts, J., \& Smith, S. (2002). Ceteris Paribus Lost. Erkenntnis, 57(3), 281-301.

Feldman, R. (2000). The ethics of belief. Philosophy and Phenomenological Research, 60(3), 667-695.

Finlay, S. (2008). The error in the error theory. Australasian Journal of Philosophy, 86(3), 347-369.

Finlay, S. (2009). Oughts and ends. Philosophical Studies, 143(3), 315-340.

Fletcher, G. (2017). Pain for the moral error theory? A New companions-in-guilt argument. Australasian Journal of Philosophy. https://doi.org/10.1080/00048402.2017.1386693.

Foot, P. (1972). Morality as a system of hypothetical imperatives. Philosophical Review, 81(3), 305-316.

Hare, R. M. (1981). Moral thinking: Its levels, method, and point. Oxford: Oxford University Press.

Husi, S. (2013). Why reasons skepticism is not self-defeating. European Journal of Philosophy, 21(3), 424-449.

Hyun, A., \& Sampson, E. (2014). On believing the error theory. Journal of Philosophy, 111(11), 631-640.

Joyce, R. (2001). The myth of morality. Cambridge: Cambridge University Press.

Kelly, T. (2003). Epistemic rationality as instrumental rationality: A critique. Philosophy and Phenomenological Research, 66, 612-640.

Kelly, T. (2007). Evidence and normativity: A reply to Leite. Philosophy and Phenomenological Research, 75, 565-574.

Lillehammer, H., \& Möller, N. (2015). We can believe the Error Theory. Ethical Theory and Moral Practice, $18(3), 453-459$.

Lord, E., \& Maguire, B. (Eds.). (2016). Weighing reasons. Oxford: Oxford University Press.

Mackie, J. L. (1990). Ethics: Inventing right and wrong. London: Penguin.

McKeever, S., \& Ridge, M. (2006). Principled ethics: Generalism as a regulative ideal. Oxford: Oxford University Press.

Nottelmann, N. (2017). The deontological conception of epistemic justification: A reassessment. Synthese, 190(12), 2219-2241.

Olson, J. (2011). Error theory and reasons for belief. In A. Reisner \& A. Steglich-Petersen (Eds.), Reasons for belief (pp. 75-93). Cambridge: Cambridge University Press.

Olson, J. (2014). Moral error theory: History, critique, defence. Oxford: Oxford University Press.

Parfit, D. (2017). On what matters: Volume three. Oxford: Oxford University Press.

Peels, R. (2017). Responsible belief: A theory in ethics and epistemology. Oxford: Oxford University Press.

Rowland, R. (2016). In defence of good Simpliciter. Philosophical Studies, 173, 1371-1391.

Sampson, E. (2015). Against Scanlon's theory of the strength of practical reasons. Journal of Ethics and Social Philosophy, 3, 1-6.

Scanlon, T. M. (1998). What we owe to each other. Cambridge, MA: Harvard University Press.

Scanlon, T. M. (2014). Being realistic about reasons. Oxford: Oxford University Press.

Schroeder, M. (2007). Slaves of the passions. Oxford: Oxford University Press.

Sher, G. (2006). In praise of blame. Oxford: Oxford University Press.

Stratton-Lake, P. (2002). Introduction. In P. Stratton-Lake (Ed.), W.D.Ross: The right and the good. Oxford: Clarendon Press.

Streumer, B. (2013). Can we believe the error theory? Journal of Philosophy, 110, 194-212.

Thomson, J. J. (1994). Goodness and Utilitarianism. Proceedings and Addresses of the American Philosophical Association, 67(4), 7-21.

Tiffany, E. (2007). Deflationary normative pluralism. Canadian Journal of Philosophy, 37(5), 231-262.

Vayrynen, P. (2006). Moral generalism: Enjoy in moderation. Ethics, 116, 707-741.

Vayrynen, P. (2009). A theory of hedged moral principles. Oxford Studies in Metaethics, 4, 91-132.

Williams, B. (2008). "Ethical Consistency" in his Problems of the Self. Cambridge: Cambridge University Press.

Publisher's Note Springer Nature remains neutral with regard to jurisdictional claims in published maps and institutional affiliations. 